\title{
Factors associated with protein consumption in elderly
}

\author{
Fatores associados ao consumo
}

proteico de idosos

\author{
Natália GASPARETO1 \\ Ágatha Nogueira PREVIDELLI ${ }^{2}$ \\ Rita de Cássia de AQUINO'
}

\section{A B S T R A C T}

\section{Objective}

We evaluated factors associated with protein consumption by the elderly.

\section{Methods}

We performed a cross-sectional study in a sample of 295 elderly consumers of health facilities in São Caetano do Sul, São Paulo, Brazil. Protein consumption data ( $\mathrm{g}$ and $\mathrm{g} / \mathrm{kg}$ ) were obtained through 24-hour dietary recalls, which was reapplied in a $30 \%$ sub-sample to estimate habitual consumption, with an interval of two weeks. The association between protein consumption and sociodemographic, economic, health, and dietary variables was tested using multiple linear regression.

\section{Results}

There was a positive association between protein consumption ( $\mathrm{g}$ and $\mathrm{g} / \mathrm{kg}$ ) and better Brazilian Healthy Eating Index-Revised, between protein consumption ( $\mathrm{g}$ ) and male sex, and a negative association between protein consumption ( $\mathrm{g} / \mathrm{kg}$ ) and greater calf circumference. Higher average protein consumption ( $\mathrm{g}$ or $\mathrm{g} / \mathrm{kg}$ ) was observed among married elderly, individuals with higher income and schooling, who were economically active, eutrophic, without dyslipidemia and symptoms of dysphagia, who consumed three main meals and an intermediate snack.

\section{Conclusion}

The results showed that protein consumption was associated with diet quality, sex, and calf circumference. The identification of elderly groups prone to protein inadequacy may direct individual and collective interventions to prevent muscle mass reduction and its implications, such as sarcopenia and other adverse outcomes.

Keywords: Aged. Aging. Dietary proteins. Food consumption.

\footnotetext{
1 Universidade São Judas Tadeu, Centro de Pesquisa, Programa de Pós-Graduação Stricto Sensu em Ciências do Envelhecimento. R. Taquari, 546, Mooca, 03166-000, São Paulo, SP, Brasil. Correspondência para/Correspondence to: N GASPARETO. E-mail: <ng.nutri@yahoo.com.br>.

2 Universidade São Judas Tadeu, Faculdade de Ciências Biológicas, Curso de Nutrição. São Paulo, SP, Brasil.
} 


\section{R E S U M O}

\section{Objetivo}

Avaliar os fatores associados ao consumo proteico de idosos.

\section{Métodos}

Estudo transversal descritivo realizado com 295 idosos usuários de centros para terceira idade e unidades de saúde do Município de São Caetano do Sul, São Paulo. O consumo proteico (g e g/kg) foi obtido na avaliação do recordatório de 24 horas, que foi reaplicado numa subamostra de 30\% para estimar o consumo habitual, com intervalo máximo de duas semanas. A associação entre proteína e variáveis sociodemográficas, econômica, de saúde e dietéticas foram testadas por meio de regressão linear múltipla.

\section{Resultados}

Houve associação positiva entre o consumo de proteína ( $\mathrm{g}$ e $\mathrm{g} / \mathrm{kg}$ ) e melhor Índice de Qualidade da Dieta Revisado, entre o consumo de proteína ( $g$ ) com o sexo masculino, e associação negativa entre proteína $(\mathrm{g} / \mathrm{kg}$ ) e maior circunferência da panturrilha. Maior consumo médio de proteína (g elou g/kg) foi observado entre idosos casados, com maior renda e escolaridade, economicamente ativos, eutróficos, sem dislipidemia e sintomas de disfagia, que consumiram as três refeições principais e lanche intermediário.

\section{Conclusão}

Os resultados demonstraram que o consumo proteico foi associado à qualidade da dieta, sexo e circunferência da panturrilha. A identificação de grupos de idosos propensos à inadequação proteica pode direcionar intervenções individuais e coletivas com intuito de prevenir a redução de massa muscular e suas implicações, como sarcopenia e outros desfechos adversos.

Palavras-chave: Idoso. Envelhecimento. Proteínas na dieta. Consumo de alimentos.

\section{INTRODUCTION}

The growth of the elderly population is a worldwide phenomenon, and a demographic transition has been rapidly taking place. Statistical projections indicate that by 2025 Brazil will probably have $15 \%$ of its population (more than 30 million people) consisting of elderly, which will place the country sixth in the world [1].

The health of the elderly is influenced by a diet that provides quantity and adequate proportions of nutrients. Thus, proteins play a key role in different processes, such as growth, muscle function, and immunity [2]. An adequate consumption may minimize the loss of muscle mass common to aging. It is estimated that in Brazil, $17 \%$ of the elderly population have sarcopenia, a condition that increases the risk of falls, decline in functionality, and mortality [3]. According to the European Working Group on Sarcopenia in Older People, this is a syndrome characterized by a progressive loss of muscle mass associated with a decrease in strength or function [4]. The decrease in muscle strength associated with age, known as dynapenia, may also be considered a determining risk factor for mortality [5].

According to the recommendation of the Dietary Reference Intakes (DRI) [6], protein consumption in adults and older people should be $0.8 \mathrm{~g} / \mathrm{kg} /$ day (Recommended Dietary Allowance $[R D A])$. However, there seems to be a consensus among large groups, such as the Study Group on Meeting Protein Needs of Older People (PROT-AGE Study Group) [7] and the The European Society for Clinical Nutrition and Metabolism (ESPEN) Expert Group [8], as they propose a greater consumption of $1.0 \mathrm{~g} / \mathrm{kg} /$ day to $1.5 \mathrm{~g} / \mathrm{kg} /$ day to minimize the loss of lean body mass that occurs with aging, and to supply the necessary intake in chronic conditions and inflammation, which favor catabolism $[7,8]$.

Despite the importance of protein to the elderly's nutrition and health, few studies have assessed the factors that may influence 
their consumption, such as social, economic, cultural, dietary, and health aspects. Some factors that may influence the consumption of protein include low energy intake, tooth loss, anorexia, food insecurity, and an increase in physical dependence. All these factors may be pronounced in older people living in longstay institutions or hospitals and in developing countries $[2,9]$.

Focusing on exploring nutritional strategies to guarantee the adequate intake of protein in older people, this study aimed at assessing factors associated with protein consumption by them.

\section{METHODS}

Our team completed a cross-sectional, descriptive study with non-probabilistic sampling, in which sampling was for convenience. Individuals aged 60 years or above were included in the study. They frequented health units and centers for the elderly in the municipality of São Caetano do Sul, São Paulo, Brazil. They all gave Informed consent. Data collection occurred between February 2014 and February 2015.

Data were collected by a team of duly trained nutritionists, who used a semi-structured questionnaire composed of demographic data (age, sex, education, marital status, familycomposition, and income), health data such as smoking, selfreported diseases (diabetes Mellitus, hypertension, dyslipidemia, osteoporosis, symptoms of dysphagia, and stomach pain or heartburn), condition of teeth, and anthropometry.

To calculate the Body Mass Index (BMI), body mass and height were measured by a mechanical scale with a $0.1 \mathrm{~kg}$ scale stadiometer and a 300-pound maximum load. The elderly people were wearing light clothes, they were barefoot and positioned with feet together on the center of the scale. Also, they were standing erect with their arms extended along their body, and they were staring straight ahead.
BMI was classified according to the cut-off points used in the study Saúde, Bem-estar e Envelhecimento (Health, Well-being and Aging), which researched older people in Latin American countries, including Brazil [10].

The evaluation of dynapenia was performed by grip strength. The greater value of three measures was used with applied force for five seconds in Sahean ${ }^{\circledR}$ dynamometer device of $100 \mathrm{~kg} / \mathrm{kg}$ capacity. Men were considered dynapenic if their values were below $26 \mathrm{kgf} / \mathrm{kg}$, and women were considered dynapenic if their values were below $16 \mathrm{kgf} / \mathrm{kg}$ [11]. An inelastic tape measure was employed to evaluate calf circumference, and it was considered inappropriate when $\leq 34 \mathrm{~cm}$ for men and $\leq 33 \mathrm{~cm}$ for women according to a cutoff point proposed by Barbosa Silva et al. [12] for identification of low appendicular muscle mass in a study with older Brazilian people.

A 24-hour Dietary Recall (24HR) was employed to assess food consumption. To estimate the usual intake, the 24HR was personally reused in $30 \%$ of the sample, with a maximum 15-day interval. The elderly were instructed to take note of the food consumed before the interview, with the aid of a manual with pictures of usual measures to reduce the risk of forgetting when collecting the $24 \mathrm{HR}$. All days of the week and months of the year were considered, as well as the variability of dietary patterns in different seasons. The usual measures were converted into $\mathrm{g} / \mathrm{mL}$, and the Nutrition Data System for Research ${ }^{\circledR}$ was employed to calculate nutrients. Also, the Multiple Source Method $^{\circledR}$ (German Institute of Human Nutrition Potsdam-Rehbruecke, Nuthetal, Germany) free software was employed to estimate the usual consumption.

The protein consumption was calculated according to the total protein consumed per day in $\mathrm{g}$ and $\mathrm{g} / \mathrm{kg}$. For this last calculation, an adjustment already used in studies of the National Health and Nutrition Examination Survey $[13,14]$ was made to minimize the underestimation or 
overestimation of consumption in malnourished or overweight individuals. In this study, Pan American Health Organization cutoff points [10] were adopted as reference, i.e., in the older people classified as malnourished, the weight corresponding to a $23 \mathrm{~kg} / \mathrm{m}^{2} \mathrm{BMI}$ was considered; for overweight or obese individuals, the weight corresponding to a $28 \mathrm{~kg} / \mathrm{m}^{2}$ BMI was considered. They were established as the minimum and maximum limits for the classification of normal weight, respectively.

An inadequate consumption of protein was calculated based on the DRI [6] of the Institute of Medicine/Food and Nutrition Board, considering a $0.66 \mathrm{~g} / \mathrm{kg} /$ day cutoff value corresponding to the Estimated Average Requirement (EAR).

The Brazilian Healthy Eating Index (BHEl), composed of 10 diet components (results previously described) [15], was considered a dietary variable, and it was divided into tertile for analysis. The number of meals was also considered a dietary variable; it was categorized into three groups: $3+$ (consumption of three main meals - breakfast, lunch, and dinner - and at least an in-between snack); 3 (consumption of the three main meals only); $2+$ (consumption of two main meals - breakfast and lunch or dinner - and at least one in-between snack).

A logarithmic transformation of the dependent variable for a normal distribution was employed to test the factors related to protein consumption; one logarithmic model was used for the protein measure in grams, and a different one was used for the protein measure in $\mathrm{g} / \mathrm{kg}$. Firstly, univariate linear regression was carried out for all sociodemographic, economic, health, anthropometric, and dietary variables. The $p \leq 0.20$ variables were inserted in a multiple linear regression model, employing a stepwise forward strategy; each model was adjusted by energy (kcal) from the start. The data were statistically analyzed in the Stata ${ }^{\circledR}$ software (Data Analysis and Statistical Software 12.0, College Station, Texas, United States), adopting a $5 \%$-significance level.
This study used data from the research "Identification of dietary patterns in elderly people living in the municipality of São Caetano do Sul", approved by the Research Ethics Committee of the Universidade São Judas Tadeu, n 470.062 .

\section{RES U L T S}

This study had 295 elderly participants. They were aged $69.59 \pm 0.13$ years (60 to 104 years) on average, and they were predominantly female $(85.1 \%)$.

The group's average protein consumption was $66.9 \mathrm{~g}$ and $1.03 \mathrm{~g} / \mathrm{kg}$. It was observed that $21.7 \%$ of the elderly individuals $(n=64)$ presented a protein consumption $(\mathrm{g} / \mathrm{kg})$ below the recommended $0.8 \mathrm{~g} / \mathrm{kg}$ (RDA), and a prevalence of inadequacy of $8.5 \%$ was obtained, i.e., for 25 elderly individuals, the usual consumption was lower than $0.66 \mathrm{~g} / \mathrm{kg}$ (EAR).

There was astatistically significant difference for protein consumption $(\mathrm{g} / \mathrm{kg})$ according to sex, with a higher consumption among men. Regarding protein consumption (g), differences statistically significant for sex, marital status, activity, education, and income were found. The highest consumption was observed among the elderly males, individuals married, economically active in relation to housewives, with higher income and schooling in relation to the lower range. Regarding income, there was a positive relationship with protein consumption ( $\mathrm{g}$ ) as a continuous variable (Table 1).

Considering health characteristics and anthropometry, there was a statistically significant difference regarding protein consumption $(\mathrm{g} / \mathrm{kg})$ for the nutritional status and calf circumference; obese individuals had a lower consumption than eutrophic ones and elderly with adequate calf circumference. Regarding protein consumption (g), there was a statistically significant difference for some self-reported illnesses, with a higher consumption among the elderly people without 
dyslipidemia and without symptoms of dysphagia. The BHEI and the number of meals showed a difference in the two forms of protein consumption. There was a positive relationship between $\mathrm{BHEl}$ and protein consumption, and a higher consumption among the elderly people with consumption of three main meals and an intermediate snack $(3+)$ compared to the ones who did not have lunch or dinner (2+) (Table 2).
The multivariate analysis revealed an association between the consumption of total protein (g), and sex and BHEI. The highest consumption was found among the male elderly and the elderly with the best BHEl. The protein $(\mathrm{g} / \mathrm{kg})$ showed results similar to BHEI and an inverse association with an adequate calf circumference (Table 3). The models were adjusted for consumption of energy, fibers, carbohydrates,

Table 1. Socio-demographic and economic characteristics of the elderly people living in the municipality of São Caetano do Sul (SP) Brazil, and association with protein consumption ( $\mathrm{g}$ and $\mathrm{g} / \mathrm{kg}$ ).

\begin{tabular}{|c|c|c|c|c|c|c|c|c|c|c|c|c|}
\hline \multirow{3}{*}{ Variables } & \multirow{3}{*}{$\mathrm{n}$} & \multirow{3}{*}{$\%$} & \multicolumn{5}{|c|}{ Total protein (g) } & \multicolumn{5}{|c|}{ Protein (g/kg) } \\
\hline & & & \multirow{2}{*}{ Mean } & & \multirow{2}{*}{ SD } & \multicolumn{2}{|c|}{ Univariate } & \multirow{2}{*}{ Mean } & & \multirow{2}{*}{ SD } & \multicolumn{2}{|c|}{ Univariate } \\
\hline & & & & & & $\beta$ & $p$ & & & & $\beta$ & $p$ \\
\hline \multicolumn{13}{|l|}{ Sex } \\
\hline Female & 251 & 85.1 & 64.30 & \pm & 1.37 & 1.00 & & 1.01 & \pm & 1.39 & 1.00 & \\
\hline Male & 44 & 14.9 & 84.22 & \pm & 1.36 & 0.27 & $<0.001$ & 1.18 & \pm & 1.37 & 0.16 & 0.003 \\
\hline \multicolumn{13}{|l|}{ Marital status } \\
\hline Married & 132 & 44.7 & 71.71 & \pm & 1.39 & 1.00 & & 1.07 & \pm & 1.39 & 1.00 & \\
\hline Separated or divorced & 56 & 19.0 & 64.12 & \pm & 1.30 & -0.11 & 0.031 & 0.98 & \pm & 1.34 & -0.09 & 0.103 \\
\hline A widow/widower & 107 & 36.3 & 62.90 & \pm & 1.41 & -0.13 & 0.002 & 1.01 & \pm & 1.43 & -0.06 & 0.181 \\
\hline \multicolumn{13}{|l|}{ Age group } \\
\hline $60<71$ years & 142 & 48.1 & 69.20 & \pm & 1.38 & 1.00 & & 1.04 & \pm & 1.40 & 1.00 & \\
\hline$\geq 71$ years & 153 & 51.9 & 64.91 & \pm & 1.40 & -0.06 & 0.096 & 1.02 & \pm & 1.40 & -0.02 & 0.581 \\
\hline \multicolumn{13}{|l|}{ Years of schooling } \\
\hline 0 to 4 years & 123 & 41.7 & 65.04 & \pm & 1.42 & 1.00 & & 1.03 & \pm & 1.42 & 1.00 & \\
\hline 5 to 8 years & 62 & 21.0 & 64.01 & \pm & 1.43 & -0.02 & 0.754 & 1.00 & \pm & 1.45 & -0.03 & 0.583 \\
\hline 9 to 11 years & 53 & 18.0 & 69.23 & \pm & 1.35 & 0.06 & 0.246 & 1.03 & \pm & 1.39 & 0.00 & 0.943 \\
\hline 12 years or more & 57 & 19.3 & 72.51 & \pm & 1.31 & 0.11 & 0.039 & 1.08 & \pm & 1.32 & 0.05 & 0.387 \\
\hline \multicolumn{13}{|l|}{ Living situation } \\
\hline Alone & 75 & 25.4 & 63.56 & \pm & 1.33 & 1.00 & & 0.97 & \pm & 1.36 & 1.00 & \\
\hline With someone & 220 & 74.6 & 68.14 & \pm & 1.41 & 0.07 & 0.114 & 1.05 & \pm & 1.41 & 0.08 & 0.082 \\
\hline \multicolumn{13}{|l|}{ Work activity } \\
\hline Working & 27 & 9.2 & 71.86 & \pm & 1.30 & 1.00 & & 1.10 & \pm & 1.30 & 1.00 & \\
\hline Retired & 178 & 61.0 & 69.01 & \pm & 1.36 & -0.04 & 0.549 & 1.06 & \pm & 1.37 & -0.04 & 0.546 \\
\hline Housewife & 87 & 29.8 & 61.98 & \pm & 1.46 & -0.15 & 0.040 & 0.97 & \pm & 1.47 & -0.13 & 0.079 \\
\hline \multicolumn{13}{|l|}{ Per capita income (MW) } \\
\hline Up to $1 \mathrm{MW}$ & 91 & 31.5 & 64.45 & \pm & 1.42 & 1.00 & & 1.01 & \pm & 1.43 & 1.00 & \\
\hline$>1 \mathrm{MW}$ and $\leq 3 \mathrm{MW}$ & 130 & 45.0 & 66.30 & \pm & 1.41 & 0.03 & 0.528 & 1.03 & \pm & 1.42 & 0.01 & 0.773 \\
\hline$>3 \mathrm{MW}$ & 68 & 23.5 & 71.48 & \pm & 1.30 & 0.10 & 0.050 & 1.07 & \pm & 1.32 & 0.05 & 0.343 \\
\hline Continuous variables & 295 & 100.0 & 66.94 & \pm & 1.39 & & & 1.03 & \pm & 1.40 & & \\
\hline Age & & - & & - & & -0.01 & 0.067 & & - & & 0.00 & 0.875 \\
\hline Income & & -- & & - & & 0.00 & 0.006 & & - & & 0.00 & 0.182 \\
\hline
\end{tabular}

Note: MW: Minimum Wage $(\mathrm{R} \$ 724,00)$; SD: Standard Deviation. 
Table 2. Health, dietary and anthropometric characteristics of elderly people living in the municipality of São Caetano do Sul (SP), Brazil, and association with protein consumption ( $\mathrm{g}$ and $\mathrm{g} / \mathrm{kg}$ ).

1 of 2

\begin{tabular}{|c|c|c|c|c|c|c|c|c|c|c|c|c|}
\hline \multirow{3}{*}{ Variables } & \multirow{3}{*}{$n$} & \multirow{3}{*}{$\%$} & \multicolumn{5}{|c|}{ Total protein (g) } & \multicolumn{5}{|c|}{ Protein (g/kg) } \\
\hline & & & \multirow{2}{*}{ Mean } & \multirow{2}{*}{\multicolumn{2}{|c|}{ SD }} & \multicolumn{2}{|c|}{ Univariate } & \multirow{2}{*}{ Mean } & & \multirow{2}{*}{ SD } & \multicolumn{2}{|c|}{ Univariate } \\
\hline & & & & & & $\beta$ & $p$ & & & & $\beta$ & $p$ \\
\hline \multicolumn{13}{|l|}{ Nutritional status } \\
\hline Eutrophic & 125 & 42.4 & 68.55 & \pm & 1.38 & 1.00 & & 1.07 & \pm & 1.38 & 1.00 & \\
\hline Malnutrition & 41 & 13.9 & 67.57 & \pm & 1.43 & -0.01 & 0.809 & 1.20 & \pm & 1.43 & 0.11 & 0.056 \\
\hline Overweight & 38 & 12.9 & 68.79 & \pm & 1.36 & 0.00 & 0.953 & 0.99 & \pm & 1.36 & -0.08 & 0.190 \\
\hline Obesity & 91 & 30.8 & 63.80 & \pm & 1.39 & -0.07 & 0.115 & 0.94 & \pm & 1.39 & -0.13 & 0.003 \\
\hline \multicolumn{13}{|l|}{ Calf circumference } \\
\hline Inadequate & 85 & 28.8 & 67.75 & \pm & 1.37 & 1.00 & & 1.14 & \pm & 1.38 & 1.00 & \\
\hline Adequate & 210 & 71.2 & 66.62 & \pm & 1.40 & -0.02 & 0.691 & 0.99 & \pm & 1.40 & -0.14 & 0.001 \\
\hline \multicolumn{13}{|l|}{ Grip strength } \\
\hline Non-dynapenic & 253 & 85.8 & 66.27 & \pm & 1.40 & 1.00 & & 1.02 & \pm & 1.41 & 1.00 & \\
\hline Dynapenic & 42 & 14.2 & 71.13 & \pm & 1.34 & 0.07 & 0.198 & 1.11 & \pm & 1.35 & 0.08 & 0.141 \\
\hline \multicolumn{13}{|l|}{ Smoking } \\
\hline No & 282 & 95.6 & 67.23 & \pm & 1.39 & 1.00 & & 1.04 & \pm & 1.40 & 1.00 & \\
\hline Yes & 13 & 4.4 & 60.93 & \pm & 1.46 & -0.10 & 0.292 & 0.94 & \pm & 1.48 & -0.10 & 0.315 \\
\hline \multicolumn{13}{|l|}{ Diseases } \\
\hline \multicolumn{13}{|l|}{ Hypertension (SAH) } \\
\hline No & 131 & 44.4 & 68.00 & \pm & 1.43 & 1.00 & & 1.05 & \pm & 1.43 & 1.00 & \\
\hline Yes & 164 & 55.6 & 66.10 & \pm & 1.36 & -0.03 & 0.463 & 1.02 & \pm & 1.37 & -0.03 & 0,416 \\
\hline \multicolumn{13}{|l|}{ Diabetes Mellitus } \\
\hline No & 231 & 78.3 & 67.15 & \pm & 1.40 & 1.00 & & 1.04 & \pm & 1.40 & 1.00 & \\
\hline Yes & 64 & 21.7 & 66.19 & \pm & 1.37 & -0.01 & 0.756 & 1.01 & \pm & 1.41 & -0.03 & 0,571 \\
\hline \multicolumn{13}{|l|}{ Dyslipidemia } \\
\hline No & 171 & 58.0 & 69.43 & \pm & 1.40 & 1.00 & & 1.06 & \pm & 1.40 & 1.00 & \\
\hline Yes & 124 & 42.0 & 63.65 & \pm & 1.37 & -0.09 & 0.025 & 0.99 & \pm & 1.40 & -0.06 & 0,109 \\
\hline \multicolumn{13}{|l|}{ Osteoporosis } \\
\hline No & 217 & 73.6 & 67.07 & \pm & 1.42 & 1.00 & & 1.02 & \pm & 1.42 & 1.00 & \\
\hline Yes & 78 & 24.4 & 66.59 & \pm & 1.31 & -0.01 & 0.871 & 1.07 & \pm & 1.35 & 0.05 & 0,268 \\
\hline \multicolumn{13}{|c|}{ Dysphagia symptoms } \\
\hline No & 254 & 86.1 & 67.96 & \pm & 1.39 & 1.00 & & 1.05 & \pm & 1.40 & 1.00 & \\
\hline Yes & 41 & 13.9 & 60.98 & \pm & 1.36 & -0.11 & 0.050 & 0.96 & \pm & 1.40 & -0.09 & 0,115 \\
\hline Stomachache/Hea & & & & & & & & & & & & \\
\hline No & 260 & 88.1 & 67.41 & \pm & 1.39 & 1.00 & & 1.04 & \pm & 1.40 & 1.00 & \\
\hline Yes & 35 & 11.9 & 63.26 & \pm & 1.39 & -0.06 & 0.286 & 1.00 & \pm & 1.41 & -0.04 & 0,562 \\
\hline Dentition & & & & & & & & & & & & \\
\hline Own & 124 & 42.0 & 67.77 & \pm & 1.42 & 1.00 & & 1.03 & \pm & 1.41 & 1.00 & \\
\hline Use of prosthesis & 171 & 58.0 & 66.35 & \pm & 1.37 & -0.02 & 0.584 & 1.03 & \pm & 1.39 & 0.00 & 0.949 \\
\hline Number of meals & & & & & & & & & & & & \\
\hline $3+$ & 254 & 86.1 & 67.65 & \pm & 1.38 & 1.00 & & 1.05 & \pm & 1.39 & 1.00 & \\
\hline 3 & 29 & 9.8 & 67.38 & \pm & 1.35 & 0.00 & 0.950 & 1.03 & \pm & 1.32 & -0.01 & 0.876 \\
\hline $2+$ & 12 & 4.1 & 52.72 & \pm & 1.68 & -0.25 & 0.010 & 0.79 & \pm & 1.58 & -0.28 & 0.004 \\
\hline
\end{tabular}


Table 2. Health, dietary and anthropometric characteristics of elderly people living in the municipality of São Caetano do Sul (SP), Brazil, and association with protein consumption ( $\mathrm{g}$ and $\mathrm{g} / \mathrm{kg}$ ).

2 of 2

\begin{tabular}{|c|c|c|c|c|c|c|c|c|c|c|c|c|}
\hline \multirow{3}{*}{ Variables } & \multirow{3}{*}{$\mathrm{n}$} & \multirow{3}{*}{$\%$} & \multicolumn{5}{|c|}{ Total protein $(\mathrm{g})$} & \multicolumn{5}{|c|}{ Protein $(\mathrm{g} / \mathrm{kg})$} \\
\hline & & & \multirow{2}{*}{ Mean } & \multirow{2}{*}{\multicolumn{2}{|c|}{ SD }} & \multicolumn{2}{|c|}{ Univariate } & \multirow{2}{*}{ Mean } & \multirow{2}{*}{\multicolumn{2}{|c|}{ SD }} & \multicolumn{2}{|c|}{ Univariate } \\
\hline & & & & & & $\beta$ & $p$ & & & & $\beta$ & $p$ \\
\hline \multicolumn{13}{|l|}{ Brazilian Healthy Eating Index } \\
\hline 1st tertile & 99 & 33.6 & 58.09 & \pm & 1.42 & 1.00 & & 0.92 & \pm & 1.43 & 1.00 & \\
\hline 2nd tertile & 98 & 33.2 & 68.92 & \pm & 1.37 & 0.17 & $<0.001$ & 1.05 & \pm & 1.40 & 0.13 & 0.004 \\
\hline 3rd tertile & 98 & 33.2 & 75.03 & \pm & 1.30 & 0.26 & $<0.001$ & 1.14 & \pm & 1.31 & 0.21 & $<0.001$ \\
\hline Continuous variables & 295 & 100.0 & 66.94 & \pm & 1.39 & & & 1.03 & \pm & 1.40 & & \\
\hline Body Mass Index & & - & & - & & 0.00 & 0.261 & & - & & -0.02 & $<0.001$ \\
\hline Brazilian Healthy Eating Index & & - & & - & & 0.02 & $<0.001$ & & - & & 0.02 & $<0.001$ \\
\hline Calf circumference & & - & & - & & 0.00 & 0.501 & & - & & -0.01 & 0.005 \\
\hline
\end{tabular}

Note: SD: Standard Deviation.

Table 3. Association between protein consumption ( $\mathrm{g}$ and $\mathrm{g} / \mathrm{kg}$ ) and sociodemographic, economic, health, dietary and anthropometric characteristics of elderly living in the municipality of São Caetano do Sul (SP), Brazil.

\begin{tabular}{|c|c|c|c|c|c|c|c|c|c|c|c|}
\hline \multirow{3}{*}{ Variables } & \multicolumn{5}{|c|}{ Total protein (g) } & \multirow{3}{*}{ Variables } & \multicolumn{5}{|c|}{ Protein (g/kg) } \\
\hline & \multirow{2}{*}{ Mean } & & \multirow{2}{*}{ SD } & \multicolumn{2}{|c|}{ Multivariate } & & \multirow{2}{*}{ Mean } & \multirow{2}{*}{\multicolumn{2}{|c|}{ SD }} & \multicolumn{2}{|c|}{ Multivariate } \\
\hline & & & & $\beta$ & $p$ & & & & & $\beta$ & $p$ \\
\hline Sex & & & & & & Calf circumference & & & & & \\
\hline Female & 64.30 & \pm & 1.37 & 1.00 & & Inadequate & 1.14 & \pm & 1.38 & 1.00 & \\
\hline Male & 84.22 & \pm & 1.36 & 0.11 & 0.008 & Adequate & 0.99 & \pm & 1.40 & -0.15 & $<0.001$ \\
\hline BHEI & 66.94 & \pm & 1.39 & 0.12 & $<0.001$ & BHEI & 1.03 & \pm & 1.40 & 0.11 & $<0.001$ \\
\hline
\end{tabular}

Note: BHEI: Brazilian Healthy Eating Index; SD: Standard Deviation.

and total fat. After an adjustment for energy, sex lost significance in the protein consumption model $(\mathrm{g} / \mathrm{kg})$. With these adjustments, there was a positive association between protein consumption and total fat and with carbohydrate consumption (data not shown).

\section{DISCUSSION}

This study aimed at evaluating the factors associated with protein consumption in elderly individuals. The consumption of protein (g) was associated with sex and BHEl; protein consumption $(\mathrm{g} / \mathrm{kg}$ ) was associated with $\mathrm{BHEl}$ and calf circumference. The univariate analyses showed a higher mean protein consumption ( $\mathrm{g}$ or $\mathrm{g} / \mathrm{kg}$ ) among the married, individuals with a higher income and education than those belonging to the lower range, those who work compared to housewives, eutrophic in relation to the obese, elderly without dyslipidemia and without symptoms of dysphagia, as well as those who consumed three main meals and at least one in-between snack (3+) compared to those who did not have lunch or dinner $(2+)$.

A cohort study by Beasley et al. [16], who evaluated more than 90,000 women aged between 50 and 79 years, found an association between greater protein consumption ( $\%$ total energy value) and a higher education and 
income, living with someone, being younger, not smoking, not having a history of Systemic Arterial Hypertension (SAH), and being in treatment for diabetes Mellitus, as well as other variables that are not included in this study, such as being white and having low depression scores. This study found higher consumption among older adults with higher education and income in relation to subjects of the lower range and in working professionals compared to housewives, suggesting that a higher financial, intellectual, and social access results in a higher protein consumption.

A cohort study by Haring et al. [17], which assessed cardiovascular risk in 15,792 individuals aged between 45 and 64 years, found an inverse association between protein consumption and smoking status and a positive association with education, $\mathrm{BMI}$, and use of medicine for dyslipidemia. Also, after a 22-year follow-up, it was found that the consumption of either total or animal protein had no association with a cardiovascular risk. Just like this study, the cohort study obtained a positive association between protein consumption with total fat and fiber and a negative association with carbohydrate. But, unlike the work cited, this study showed a lower protein consumption ( $g$ ) among the elderly with dyslipidemia and lower protein consumption $(\mathrm{g} / \mathrm{kg})$ among the obese subjects in relation to the eutrophic subjects, despite the weight being adjusted for BMI.

In a study carried out with individuals participating in a program for the elderly in the state of Minas Gerais, Brazil, a negative relationship between protein consumption and tooth loss was found [18]. In this study, such association was not found. Despite the high prevalence (58\%) of elderly subjects who used dental prostheses, the protein consumption did not differ from those who had their own teeth. This result suggests that the subjects' oral health be monitored. On the other hand, a lower protein consumption (g) was found among the older people who reported any symptoms of dysphagia $(p=0.005)$, demonstrating the need for further research. Badly adjusted prostheses and absence of teeth, as well as difficulty swallowing, may lead to changes in dietary patterns, with a preference for softer, easierto-chew foods. Thus, this may interfere in the consumption of some protein sources, especially meat.

This study also found a positive association between protein consumption ( $\mathrm{g}$ ) and sex; however, other studies that tested this association were not found. Nevertheless, several authors have found elderly males consume more protein (g) than females [18-22]. This difference usually loses significance when the protein $(\mathrm{g} / \mathrm{kg})$ is considered $[20,22,23]$, unlike this study, which found a difference between sexes when the protein was assessed ( $\mathrm{g}$ and $\mathrm{g} / \mathrm{kg}$ ). This result was expected, since male individuals have a greater need for total daily protein.

Regarding age, there was no difference between the evaluated ranges, which was also obtained by different authors [19-22]. This finding puts forward the hypothesis that it is not age that influences consumption, but the presence of more frequent conditions in older elderly people, such as the presence of chronic diseases, tooth loss, an increase in the time of gastric emptying, and anorexia. Although this hypothesis does not renounce age as a risk factor, many conditions related to aging that may interfere with protein consumption may be controlled and prevented, therefore optimizing the prospect of maintaining adequate food, even among the long-lived elderly.

The observation of an inverse association between protein $(\mathrm{g} / \mathrm{kg})$ and calf circumference went against expectations, since calf circumference is a parameter to estimate muscle mass in clinical practice. Beasley et al. [24], in a crosssectional study with 1,011 community-dwelling elderly, also identified an unexpected association between protein $(\mathrm{g} / \mathrm{kg})$ and anthropometric measure. The authors have noted an inverse association with skeletal mass $(\mathrm{kg})$, regardless 
of sex. On the other hand, the work of GrayDonald et al. [23], after a one-year follow-up with 422 elderly Canadians, found a protective effect between protein consumption and unintentional weight loss, regardless of energy consumption and BMI. Moreover, a cohort study by Houston et al. [25], which followed 2,066 elderly individuals for three years, found that the group with a higher consumption showed a $40 \%$ lower lean mass loss. The relationship between anthropometric measures and food consumption in cross-sectional studies should be interpreted with reservations because anthropometric measurements may not reflect recent changes in consumption.

Individuals with any health alterations may experience changes in their eating habits because of recommendations by health professionals. Lima et al. [26] assessed the diets of individuals with SAH and diabetes Mellitus, and they noticed that the suitability of food depended on existing health conditions. This may also explain the higher protein consumption observed among the elderly with diabetes Mellitus $[16,19]$ and the lower consumption among the elderly who reported dyslipidemia in this study, suggesting the replacement of food sources of carbohydrate and saturated fat (protein of animal origin), respectively.

The group showed a protein consumption average of $1.03 \mathrm{~g} / \mathrm{kg}, 21.7 \%$ of them consumed below the recommendation of $0.8 \mathrm{~g} / \mathrm{kg}$ (RDA), and $8.5 \%$ of them consumed less than $0.66 \mathrm{~g} / \mathrm{kg}$ $(E A R)$. These values are similar to what had been observed in elderly people in developed countries [14,21]. A consumption level above what is recommended provides for protection against the lean mass losses common in aging. Furthermore, this is linked to minor unintentional weight loss and a lower incidence of fragility. Different cohorts have shown the best results for elderly individuals who consumed $1.2 \mathrm{~g} / \mathrm{kg} /$ day $[16,23,25$.]

The higher protein consumption was associated with a better diet quality. The BHEI assesses the quality of diet through food components based on the pyramid of food and a food guide for the Brazilian population, which presupposes that a good score is equivalent to a varied and balanced diet [27]. It is important to highlight this result, since protein is not ingested in isolation, but within a composition of different foods and nutrients. In addition, notwithstanding the need for protein consumption in sufficient quantity, the inadequacy of other nutrients or in the fractionation and amount of protein per meal will influence the optimization of protein metabolism [9]. Moreover, a higher protein value among the older people who consumed three main meals was observed; however, no statistically significant difference was found when there was consumption of an intermediate snack. The ingestion of three meals a day is advised by the Dietary Guidelines for the Brazilian Population, as it ensures consumption of the daily requirement of protein and other nutrients [28].

A possible limitation of the study was the cross-sectional approach and the homogeneous sample in several variables. This may influence the identification of an association between protein consumption and sociodemographic, economic health, and anthropometric factors, which were observed in longitudinal studies with a larger sample number. Such limitation was not observed for the dietary variables. However, other studies for comparison were not found. The non-probabilistic sampling involves no data extrapolation for the Brazilian population. The Municipality of São Caetano do Sul has the best Human Development Index (HDI) in Brazil, with a very high $\mathrm{HDI}(0.862)$, a score close to that of cities in the South and some capitals of Brazil, and developed countries [29].

To minimize a possible underreporting of food consumption, the elderly were advised to employ the strategy of filling in the dietary recall on their consumption the day before the interview to avoid missing any food. Subsequently, they were advised to use the $24 \mathrm{HR}$ 
to confirm the information reported and fix likely inconsistencies, improving the quality of the investigation. Equally important is the adjustment of protein consumption in $\mathrm{g} / \mathrm{kg}$ for $\mathrm{BMI}$, to reduce underestimation of protein consumption in overweight individuals and overestimation in malnourished individuals. Some authors have been arguing that the assessment of protein $\mathrm{g} / \mathrm{kg}$ in overweight individuals without adjustment leads to a high prevalence of inadequacy, which could be incorrect $[13,14]$.

Few studies have evaluated the factors associated with protein consumption in the elderly, especially diet. As shown in this study, there is a positive relationship between diet quality and protein, as well as sociodemographic and health aspects, but there is no consensus yet. Nevertheless, it seems clear that some groups are more susceptible to a lower protein consumption, such as elderly with chronic illnesses, or with alteration in the oral cavity, or with lower income and education, or with an unbalanced diet (considering quantity, fractionation, and combinations of foods and nutrients), or elderly females.

\section{CONCLUSION}

An association of protein consumption and the Brazilian Healthy Eating Index, sex, and calf circumference was observed. It is recommended that further studies be conducted to confirm these findings, yet it must be pointed out that elderly females and individuals with a worse diet quality had a lower consumption. The identification of groups of elderly prone to protein inadequacy may direct individual and collective interventions to prevent reduction of muscle mass and its implications, such as sarcopenia and other adverse outcomes.

\section{CONTRIBUTORS}

N GASPARETO reviewed the literature, analyzed and interpreted the results, and wrote the article. AN PREVIDELLI performed the statistical analysis and interpreted the results. RC AQUINO designed and coordinated the study and the final proofreading of the article.

\section{REFERENCES}

1. Instituto Brasileiro de Geografia e Estatística. Projeção da população do Brasil por sexo e idade: 2000-2060. Rio de Janeiro: IBGE; 2013 [acesso 2016 dez 8]. Disponível em: http://www.ibge. gov.br/home/estatistica/populacao/projecao_da_ populacao/2013/default.shtm

2. Volpi E, Campbell WW, Dwyer JT, Johnson MA, Jensen GL, Morley JE, et al. Is the optimal level of protein intake for older adults greater than the recommended dietary allowance? J Geront A Biol Sci Med. 2013;68(6):677-81. https://doi. org/10.1093/gerona/gls229

3. Diz JB, Leopoldino AA, Moreira BS, Henschke N, Dias RC, Pereira LS, et al. Prevalence of sarcopenia in older Brazilians: A systematic review and metaanalysis. Geriatr Gerontol Int. 2016;17(1):5-16. https://doi.org/10.1111/ggi.12720

4. Cruz-Jentoft AJ, Baeyens JP, Bauer JM, Boirie $Y$, Cederholm T, Landi F, et al. Sarcopenia: European consensus on definition and diagnosis: Report of the European Working Group on sarcopenia in older people. Age Ageing. 2010;39(4):412-3.

5. Alexandre TS, Duarte YAO, Santos JLF, Wong R, Lebrao ML. Sarcopenia according to the european working group on sarcopenia in older people (EWGSOP) versus Dynapenia as a risk factor for disability in the elderly. J Nutr Health Aging. 2014;18(5):547-3. https://doi.org/10.1007/s1260 3-013-0424-x

6. Institute of Medicine. Dietary reference intakes for energy, carbohydrate, fiber, fat, fatty acids, cholesterol, protein, and amino acids. Washington: Institute of Medicine; 2005 [cited 2016 Dec 8]. Available from: http://www.nap.edu/catalog/10490/ dietary-reference-intakes- for-energy-carbohydratefiber-fat-fatty-acids-cholesterol-protein-andamino-acids-macronutrients

7. Bauer J, Biolo G, Cederholm T, Cesari M, Cruz-Jentoft, Morley JE, et al. Evidence-based recommendation for optimal dietary protein intake in older people: A position paper from the PROT-AGE Study Group. J Am Med Dir Assoc. 2013;14(8):542-59. https://doi.org/10.1016/j.jamda. 2013.05.021

8. Deutz NE, Bauer JM, Barazzoni R, Biolo G, Boirie $Y$, Bosy-Westphal A, et al. Protein intake 
and exercise for optimal muscle function with aging: Recommendations from the ESPEN Expert Group. Clin Nutr. 2014;33(6):929-36. https://doi. org/10.1016/j.clnu.2014.04.007

9. Ruiz Valenzuela RE, Ponce JA, Morales-Figueroa GG, Aguilar Muro K, Ramírez Carreón V, AlemánMateo $\mathrm{H}$. Insufficient amounts and inadequate distribution of dietary protein intake in apparently healthy older adults in a developing country: Implications for dietary strategies to prevent sarcopenia. Clin Interv Aging. 2013;8:1143-8. https://doi.org/10.2147/CIA.S49810

10. Organização Pan Americana de Saúde. Encuestra Multicêntrica - Salud Beinestar y Envejecimeiento (SABE) en América Latina e el Caribe. In: Anales da 36 Reunión del Comitê Asesor de Ivestigaciones en Salud - Informe preliminar. Washington (DC): OPAS; 2001 [acesso $2016 \mathrm{dez}$ 8]. Disponible en: https://www.opas.org/program/sabe.htm

11. Studenski SA, Peters KW, Alley DE, Cawthon PM, McLean RR, Harris TB, et al. The FNIH Sarcopenia Project: Rationale, study description, conference recommendations, and final estimates. J Gerontol A Biol Sci Med Sci. 2014;69(5):547-58. https:// doi.org/10.1093/gerona/glu010

12. Barbosa-Silva TG, Bielemann RM, Gonzalez MC, Menezes AMB. Prevalence of sarcopenia among community-dwelling elderly of a medium-sized South American city: Results of the COMO VAI? Study. J Cachexia Sarcopenia Muscle. 2016;7(2):136-43. https://doi.org/10.1002/jcsm. 12049

13. Fulgoni VL 3rd. Current protein intake in America: Analysis of the National Health and Nutrition Examination Survey, 2003-2004. Am J Clin Nutr. 2008;87(Suppl.):1554S-7S.

14. Berner LA, Becker G, Wise M, Doi J. Characterization of dietary protein among older adults in the United States: amount, animal sources, and meal patterns. J Acad Nutr Diet. 2013;113(6):809-15. https://doi.org/10.1016/j.jand. 2013.01.014

15. Freitas TI, Previdelli AN, Ferreira MPN, Marques KM, Goulart RMM, Aquino RC. Factors associated with diet quality of older adults. Rev Nutr. 2017;30(3):297-306. https://doi.org/10.15 90/167 8-98652017000300003

16. Beasley JM, LaCroix AZ, Neuhouser ML, Huang $\mathrm{Y}$, Tinker $\mathrm{L}$, Woods $\mathrm{N}$, et al. Protein intake and incident frailty in the Women's Health Initiative observational study. J Am Geriatr Soc. 2010;58(6):1063-71. https://doi.org/10.1111/j.15 32-5415.2010.02866.x
17. Haring B, Gronroos N, Nettleton JA, von Ballmoos MC, Selvin E, Alonso A. Dietary protein intake and coronary heart disease in large community based cohort: Results from Atherosclerosis Risk in Communities (ARIC) study. PLoS One. 2014;9(10). https://doi.org/10.1371/journal.pone.0109552

18. Abreu WC, Franceschini SCC, Tinoco ALA, Pereira CAS, Silva MMS. Inadequação no consumo alimentar e fatores interferentes na ingestão energética de idosos matriculados no Programa Municipal da Terceira Idade de Viçosa (MG). Rev Baiana Saúde Pública. 2008;32(2):190-202.

19. Venturini CD, Engroff $P$, Sgnaolim $V$, El Kik RM, Morrone FB, Silva Filho IG, et al. Consumo de nutrientes em idosos residentes em Porto Alegre (RS), Brasil: um estudo de base populacional. Ciênc Saúde Coletiva. 2015;20(12):3701-11. https://doi. org/10.1590/1413-812320152012.01432015

20. Volkert D, Kreuel K, Heseker H, Stehle P. Energy and nutrient intake of young-old, old-old and very-old elderly in Germany. Eur J Clin Nutr. 2004;58(8):1190-200. https://doi.org/10.1038/sj. ejcn. 1601950

21. Tieland $M$, Borgonjen-Van den Berg KJ, van Loon LJ, de Groot LC. Dietary protein intake in community-dwelling, frail, and institutionalized elderly people: Scope for improvement. Eur J Nutr. 2012;51(2):173-9. https://doi.org/10.1007/ s00394-011-0203-6

22. Tieland M, Borgonjen-Van den Berg KJ, Van Loon LJ, de Groot LC. Dietary Protein Intake in Dutch Elderly People: A Focus on Protein Sources. Nutrients. 2015;7(12):9697-706. https://doi.org/10. 3390/nu7125496

23. Gray-Donald K, St-Arnaud-McKenzie D, Gaudreau P, Morais JA, Shatenstein B, Payette H. Protein intake protects against weight loss in healthy community-dwelling older adults. J Nutr. 2014;144(3):321-6. https://doi.org/10.3945/jn.113. 184705

24. Beasley JM, Deierlein AL, Morland KB, Granieri EC, Spark A. Is meeting the Recommended Dietary Allowance (RDA) for Protein Related to Body Composition among older adults?: Results from the Cardiovascular Health of Seniors and Built Environment Study. J Nutr Health Aging. 2016;20(8):790-6. https://doi.org/10.1007/s126 03-015-0707-5

25. Houston DK, Nicklas BJ, Ding J, Harris TB, Tylavsky FA, Newman $A B$, et al. Dietary protein intake is associated with lean mass change in older, community-dwelling adults: The Health, Aging, and Body Composition (Health $A B C$ ) study. Am J Clin Nutr. 2008;87(1):150-5.

26. Lima LA, Nedel FB, Olinto MTA, Baldisserotto J. Food habits of hypertensive and diabetics cared 
for in a Primary Health Care service in the South of Brazil. Rev Nutr. 2015;28(2):197-206. https://doi. org/10.1590/1415-52732015000200008

27. Previdelli AN, Andrade SC, Pires MM, Ferreira SMG, Fisberg RM, Marchioni DM. Índice de qualidade da dieta revisado para a população brasileira. Rev Saúde Pública. 2011;45(4):794-98. https://doi. org/10.1590/S0034-89102011005000035

28. Ministério da Saúde (Brasil). Secretaria de Atenção à Saúde. Guia alimentar para a população brasileira. $2^{a}$ ed. Brasília: Ministério da Saúde; 2014 [acesso 2016 dez 8]. Disponível em: http:// portalsaude.saude.gov.br/images/pdf/2014/
novembro/05/Guia-Alimentar-para-a-popbrasiliera-Miolo-PDF-Internet.pdf

29. Programa das Nações Unidas para o Desenvolvimento, Instituto de Pesquisa Econômica Aplicada, Fundação João Pinheiro. O índice de desenvolvimento humano municipal brasileiro. Série Atlas do Desenvolvimento Humano no Brasil. Brasília: PNUD; 2013 [acesso 2016 dez 8]. Disponivel em: http://www.undp.org/content/ brazil/pt/home/library/idh1/o-idh-brasileiro0.html

Received: January 5, 2017

Final version: August 15, 2017

Approved: September 19, 2017 